\title{
SWEET CORN (Zea mays L.) FRESH EAR YIELD IN DEPENDANCE OF GENOTYPE AND THE ENVIRONMENT
}

\author{
Jelena Srdić ${ }^{1 *}$, Zorica Pajić1 ${ }^{1}$, Milomir Filipović ${ }^{1}$
}

\begin{abstract}
Sweet corn is used as food in the milky stage of endosperm, when its kernel is tender, succulent and sweet. It is consumed in form of fresh ears, or it is industrially processed. Breeding of sweet corn has several equally important aims that are directed by the market demands and different modes of consumption. The ear yield, in sweet corn is the most important but not the only main goal of breeding. In the two year study $(2013,2014)$ we observed the effect of the genotype, year and their interactions on the yields of 8 sweet corn hybrids. Two of the hybrids were commercial and six were experimental hybrids. The field experiment was arranged according to the RCBD with four replications. Hybrids were harvested 23 days after pollination, i.e. silking. Average yield in 2013 was significantly higher (12.19 $\left.\mathrm{t} \mathrm{ha}^{-1}\right)$ than in $2014\left(11.49 \mathrm{t} \mathrm{ha}^{-}\right.$ $\left.{ }^{1}\right)$. In 2013 it ranged from $10.21 \mathrm{t} \mathrm{ha}^{-1}$ for the experimental hybrid ZP 489/1su, up to $13.52 \mathrm{t} \mathrm{ha}^{-1}$ for the commercial hybrid ZP 355su. In 2014 the lowest yielding hybrid was ZP 485/1su (10.14 $\left.\mathrm{t} \mathrm{ha}^{-1}\right)$ while the highest yielding was ZP 486/1su (13.41 $\left.\mathrm{tha}^{-1}\right)$. On average those two were also the highest $\left(13.19 \mathrm{t} \mathrm{ha}^{-1}\right)$ and the lowest yielding $\left(10.66 \mathrm{t} \mathrm{ha}^{-1}\right)$ hybrids. Statistical analysis showed that the effect of genotype and the year, as well as their interactions had significant impact on the yield performances of sweet corn hybrids.
\end{abstract}

Key words: sweet corn, ear yield, genotype

\section{Introduction}

Sweet corn is one of the most popular types of specialty corn, consumed inasmuch fresh and processed vegetable. Sweet corn is mutation of field corn at the sugary $(\mathrm{Su})$ locus located in the short arm of chromosome 4 (Lee et al. 2006; Shin et al. 2006; Sa et al. 2012; Hossain et al. 2015). This mutation affects endosperm composition by causing it to accumulate twice as much sugar and eight to ten times more water-soluble polysaccharides, than the field corn at the milky stage of endosperm development. Such kernel composition provides sweet taste and creamy texture by which sweet corn is recognizable (Pajić et al., 2008). Kernel sucrose, phytoglycogen and starch concentration are regulated by carbohydrate metabolism

Original scientific paper (Originalni naučni rad)

${ }^{1}$ Srdić J., Pajić Z., Filipović M, Maize Research Institute Zemun Polje, Slobodana Bajića 1, Belgrade, Serbia

*e-mail: jsrdic@mrizp.rs 
during kernel development. Standard sweet corn is homozygous for the sugaryl (sul) mutation. This mutation gives sweet corn its characteristic sweetness and creamy texture by increasing the concentration of sucrose and phytoglycogen (highly branched, water soluble form of starch) at harvest maturity (Creech, 1968). Sugary varietes at the milky ripening stage contain nearly three times more reducing sugar and sucrose, ten times more water soluble phytoglycogen (WSP) and one-third of the starch content of the field corn (Fisher and Boyer 1983; James et al. 1995; Feng et al. 2008). However sugar content after harvest decline very fast in sul sweet corn types (Garwood et al. 1976).

Sweet corn is harvested 20-25 days after pollination, when the content of sucrose is at maximum and the moisture content is between 74 -76\% (Rosenbrook and Andrew1970; Pajić et al. 2006). Since sucrose provides sweetness of kernel it is of the highest significance to pay attention at its content and to establish the moment when this sugar reaches maximum for harvest.

Ear yield is one of the most important traits of sweet corn especially for producers, but there are several more with as much importance as the yield itself. Favorable traits of sweet corn hybrids are uniformity of ear size, length and shape, proper kernel row configuration, depth, width and color of kernels, as well as the quality of taste (Pajić et al. 2010). Average yield of six ZP sweet corn hybrids ranged from $8.00-13.39 \mathrm{t} \mathrm{ha}^{-1}$ (Srdić and Pajić 2010), which is highly depended on genotype. It was also established that beside genotype also effect of year and different sowing densities had significant influence on fresh ear yield (Srdić et al. 2011). That research also showed that average fresh ear yield of four sweet corn hybrids raised from 8.02 up to 9.73 $\mathrm{t} \mathrm{ha}^{-1}$ when sowing densities were increased from 40,000 to 70,000 plants per ha.

The objective of this study was to determine the effect of genotype and ear on fresh ear in eight sweet corn hybrids.

\section{Material and methods}

This experiment was carried out on a slightly calcareous chernozem soil on the experiment field of Maize Research Institute, Zemun Polje during 2013 and 2014. The trial was set up according to the RCB design with four replicates. Material for this study was eight ZP sweet corn hybrids. Two of them were commercial sweet corn hybrids ZP 424su and ZP 355su and the other six were experimental hybrids. Manual sowing was performed on $17^{\text {th }}$ of April in 2013 and 23 $3^{\text {rd }}$ of April in 2014. The elementary plot was two rows with $70 \mathrm{~cm}$ inter-row distance and the size of $7 \mathrm{~m}^{2}$ and the density of 57,142 plant per ha. Harvest was performed 24 days after pollination i.e. silking, and the fresh ear yield without husk was measured from the elementary plot.

Obtained data were statistically processed by the two factorial analysis of variance, where the factor A was genotype and the factor B was year. The differences between means were tested with LSD test.

\section{Results and discussion}

Results of the analysis of variance showed that investigated factors i.e. genotype and the year, as well as their interaction had significant impact on the fresh ear yield (Tab. 1). Different meteorological conditions in two observed years had significant influence on the yield performances. Even more this trait was influenced by the genotype, which was also confirmed by the LSD test (Tab. 2). 
Table 1. ANOVA for fresh ear yield

Tabela 1. ANOVA za prinos svežeg klipa

\begin{tabular}{lcl}
\hline \multicolumn{1}{c}{ Sources of Variance } & Degrees of Freedom & Mean Square \\
\hline Replication & 3 & 0.185 \\
Hybrid & 7 & $6.098^{* *}$ \\
Year & 1 & $7.687^{*}$ \\
Hybrid x Year & 7 & $3.548^{*}$ \\
\hline
\end{tabular}

$*, * *$ - significant at $0.05,0.01$ probability level

Table 2. Average fresh ear yield of eight sweet corn hybrids

Tabela 2. Prosečan prinos svežeg klipa osam hibrida kukuruza šećerca

\begin{tabular}{lccc}
\hline \multicolumn{3}{c}{ Year } \\
\hline Hybrid & 2013 & 2014 & average \\
\hline ZP 424su & 11.43 & 11.77 & $11.60 \mathrm{bcd}$ \\
ZP 355su & 13.52 & 11.61 & $12.57 \mathrm{ab}$ \\
ZP 489/1su & 10.21 & 11.36 & $10.79 \mathrm{~cd}$ \\
ZP 481/1su & 12.80 & 10.21 & $11.51 \mathrm{bcd}$ \\
ZP 487/1su & 12.14 & 11.98 & $12.06 \mathrm{abc}$ \\
ZP 486/1su & 12.97 & 13.41 & $13.19 \mathrm{a}$ \\
ZP 485/1su & 11.18 & 10.14 & $10.66 \mathrm{~d}$ \\
ZP 484/1su & 13.26 & 11.46 & $12.36 \mathrm{ab}$ \\
\hline average & 12.19 & 11.49 & 11.84 \\
min & 10.21 & 10.14 & 10.66 \\
Max & 13.52 & 13.41 & 13.19 \\
LSD & & & 1.36 \\
\hline
\end{tabular}

Average fresh ear yield was significantly higher in the first analyzed year (2013) and it amounted $12.19 \mathrm{t} \mathrm{ha}^{-1}$, while in 2014 average fresh ear yield was $11.49 \mathrm{t} \mathrm{ha}^{-1}$ (Tab. 2).

Among eight sweet corn hybrids the highest yielding in 2013 was commercial hybrid ZP 355su, while in 2014 it was experimental hybrid ZP 486/1su, which was also the highest yielding hybrid on average for both years. These two hybrids also express desirable properties for market purposes such as uniformity of ear shape and size, proper kernel row alignment, and overall healthy and desirable appearance. Hybrid ZP 355su has very light yellow kernel, while the other has intensive yellow kernel. Hybrid ZP 486/1su had 16 kernel rows, while the number of kernel rows in ZP 355su depending on the year varied 
between 16 and 18 (Fig. 1). Both hybrids have lower stem.

The lowest yielding hybrid in 2013 was hybrid ZP 489/1su (10.21 $\left.\mathrm{t} \mathrm{ha}^{-1}\right)$, and in 2014 and on average for both years it was hybrid ZP 485/1su (10.14 and $10.66 \mathrm{t} \mathrm{ha}^{-1}$, respectively) (Tab.2). Those hybrids are still both experimental hybrids. Characteristically, those two hybrids on the contrary from the highest yielding hybrids had higher stem. Uniformity of the shape and size of their ears is also present in those hybrids. Hybrid ZP $485 / 1$ su had very deep kernel, which was also marked in ZP 489/1su, as well as the long ear. The number of kernel rows varied from $14-18$ in ZP 489/1su, while ZP 485/1su had 16 kernel rows (Fig. 1).

The number of kernel rows expressed variations over observed years in four hybrids. In 2013 all of them expressed higher number of kernel rows. The lowest number of kernel rows had hybrid ZP 489/1su in 2014 - 14, while in 2013 it had 18 kernel rows (Fig. 1). Also the large variation was expressed by the hybrid $\mathrm{ZP}$ 424 su, $16-20$ kernel rows, depending on the year. The highest number of kernel rows was observed in ZP 487/1su - 20 kernel rows. This hybrid was the second highest yielding in 2014 (11.98 $\mathrm{t} \mathrm{ha}^{-1}$ ), while in 2013 and on average it stands on the forth place (Tab. 2).

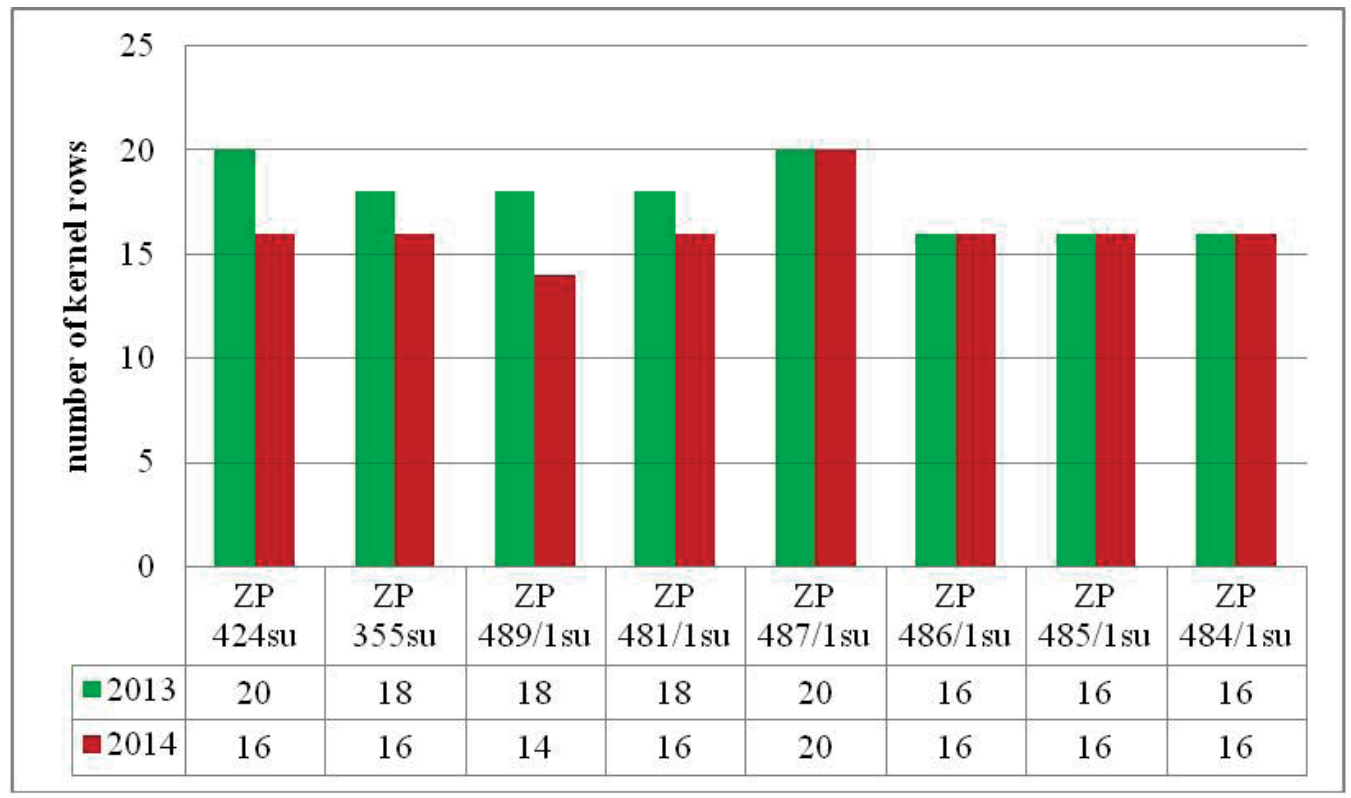

Figure 1. Number of kernel rows of eight sweet corn hybrids

Grafikon 1. Broj redova zrna osam hibrida kukuruza šećerca

\section{Conclusion}

Based on the presented results, following conclusions could be made:

Fresh ear yield of sweet corn is significantly influenced by genotype, metrological conditions in different years and the interaction of those two factors.

- $\quad$ The year 2013 was more productive, 
and significantly higher fresh ear yields were recorded in it than in 2014.

The highest yielding hybrids were commercial hybrid ZP 355su and experimental hybrid ZP 486/1su, while the lowest yielding hybrids were experimental hybrids ZP 489/1su and ZP 485/1su.

Both highest and lowest yielding hybrids had nice physical appearances, such as uniformity of shape and size of the ear.

\section{Acknowledgment}

This study was supported by the Ministry of Education, Science and Technological Development, Republic of Serbia, through Project TR 31068.

\section{References}

Creech RG (1968): Carbohydrate synthesis in maize. Adv. Agron., 20: 275.

Feng ZL, Liu J, Fu FL, Li WC (2008): Molecular mechanism of sweet and waxy in maize. Int. J. Plant Breed. Genet., 2: 93-100.

Fisher MB, Boyer C (1983): Immunological characterization of maize starch branching enzymes. Plant Physiology,72: 813-816.

Garwood DL, McArdle FJ, Vanderslice SF, Shannon JC (1976): Postharvest carbohydrate transformations and processed quality of high sugar maize genotypes. J. Am. Soc. Hort. Sci., 101: 400-404.

Hossain F, Nepolean T, Vishwakarma AK, PandeyN, Prasanna BM, Gupta HS (2015): Mapping and validation of microsatellite markers linked to sugary 1 and shrunken 2 genes in maize (Zea mays L.). J. Plant Biochem. Biotechnol., 24 (2): 135-142.

James MG, Robertson DS, Myers AM (1995):
Characterization of the maize gene sugaryl, a determinant of starch composition in kernels. Plant Cell, 7: 417-429.

Lee JK, Park JY, Kim JH, Kwon SJ, Shin JH, Hong SK, Min HK, Kim NS (2006): Genetic mapping of the Isaac-CACTA transposon in maize. Theoretical and Applied Genetics, 113: 16-22.

Pajić Z, Radosavljević M, Srdić J (2006): Promene ugljenohidratnog sastava zrna kukuruza šećerca. Zbornik naučnih radova, Institut PKB Agroekonomik, Beograd, 12: 55-65.

Pajić Z, Srdić J, Filipović M (2008): Sweet maize breeding for different consumption purposes. Journal on Processing and Energy in Agriculture, 12: 12-14.

Pajić Z, Radosavljević M, Filipović M, Tododrović G, Srdić J, Pavlov M (2010):Breeding of specialty maize for industrial purposes. Genetika 42: 57-66. Rosenbrook RW, Andrew RH (1970): Variation in carbohydrate composition in the endosperm of sweet corn (Zea mays L.) in relation to maturity. Crop Science, 10, 332-335.

Sa KJ, Park JY, Park KC, Lee JK (2012): Analysis of genetic mapping in a waxy/ dent maize RIL population using SSR and SNP markers. Genes and Genomics, 34: 157-164.

Shin JH, Kwon SJ, Lee JK, Min HK, Kim NS (2006): Genetic diversity of maize starch-synthesis genes with SNPs. Genome, 49: 1287-1296.

Srdić J, Pajić Z (2010): Nasleđivanje i korelacija prinosa klipa i randmana zrna kod kukuruza šećerca (Zea mays L. saccharata). Journal of Scientific Agricultural Research, 71: 39-45. 
Srdić J, Simić M, Videnović Ž, Pajić Z, Dragičević V (2011): Effects of genotype and sowing densities on ear yield and shelling percentage of sweet corn. AGRISAFE Final Conference $21^{\text {st }}$ $-23^{\text {rd }}$ March, Budapest, Hungary, pp. 344-347. 


\title{
UTICAJ EFEKTA GENOTIPA I SREDINE NA PRINOS KLIPA KUKURUZA ŠEĆERCA (Zea mays L.)
}

\author{
Jelena Srdić, Zorica Pajić, Milomir Filipović
}

\begin{abstract}
Sažetak
Kukuruz šećerac se koristi u mlečnoj fazi razvoja endosperma kada mu je zrno nežno, sočno i slatko. Koristi se za ishranu ljudi u svežem stanju, ili industrijski prerađen. Zahtevi tržišta i različiti načini upotrebe kukuruza šećerca usmeravaju oplemenjivače kukurza šećerca ka stvaranju ne samo visokoprinosnih hibrida. Za ovaj tip kukuruza, više nego za bilo koji drugi, veoma je bitan lep i primamljiv spoljašnji izgled klipa, sa pravilnim rasporedom zrna, a naročito su bitne organoleptičke karakteristike zrna - ukus, miris, tekstura i nežnost perikarpa. U toku dvogodišnjih ispitivanja $(2013,2014)$, posmatran je uticaj genotipa i spoljašnje sredine na prinos svežeg klipa kukuruza šećerca kod 8 hibrida. Dva hibrida ZP 355su i ZP 424su su komercijalni hibridi, dok je ostalih šest eksperimentalnih. Ogled je organizovan po RCBD principu u četiri ponavljanja. Berba je obavljena 23 dana nakon oprašivanja, tj. svilanja. Prosečan prinos svežeg klipa šećerca bio je značajno viši u 2013 godini (12.19 tha-1) od prosečnog prinosa u 2014 (11.49 t $\mathrm{ha}^{-1}$ ). Najprinosniji hibrid 2013 godine bio je ZP 355su sa $13.52 \mathrm{t} \mathrm{ha}^{-1}$, dok je u 2014 najviši prinos postigao ZP 486/1 su sa $13.41 \mathrm{t} \mathrm{ha}^{-1}$. Najniže prinose imali su ZP 489/1su $\left(10.21 \mathrm{t} \mathrm{ha}^{-1}\right) \mathrm{u} 2013 \mathrm{i}$ ZP 485/1su (10.14 t ha-1) u 2014 godini. Analizom varijanse utvrđeno je da efekat genotipa, godine, kao i njihova interakcija značajno utiču na prinos svežeg klipa kukuruza šećerca.
\end{abstract}

Ključne reči: kukuruz šećerac, prinos svežeg klipa, genotip

Primljen: 27.11.2015.

Prihvaćen: 23.02.2016. 